\title{
ANALISIS SISTEM PENGENDALIAN INTERN DALAM KAITANNYA DENGAN KEAMANANHARTA PERUSAHAAN PADA CV. KENCANA JAYA DI BANDAR LAMPUNG \\ (Study Kasus pada CV. Kencana Jaya di Bandar Lampung) \\ Habiburrahman, Universitas Bandar Lampung Ayu Widia Ningrum, Universitas Bandar Lampung Riswan, Universitas Bandar Lampung
}

\begin{abstract}
Abtract
Success or failure of the company's management is generally characterized by the ability of management to control the operational activities of the company, so that its implementation in accordance with a predetermined plan. With a good system of internal control, it is expected that the implementation of the operational activities of the company in accordance with existing plans and actions to minimize the harm to the company, so that the goal can be achieved by well planned. The problem with the CV. KENCANA JAYA is increasing doubtful receivables (loss) for 4 (four) periods, while the issue is whether a good internal control system can reduce the risk of $C V$ company property. Kencana Jaya.

The purpose of research is to determine how good internal control when connected with the implementation of the internal control system on sales and cash receipts on the $C V$. Kencana Jaya Bandar Lampung. While the information and consideration in decision making.Data collection methods used, the study of literature and field research while the method of analysis is qualitative analysis. From the results of evaluation of the system of internal control over sales and cash receipts, it can be concluded, that the system of internal control over sales has occurred geminating lending function, order by phone often does not proceed with the purchase order entry, and not proceed with the purchase order entry, and do not miss out any checks before approving loan collection. For it should be held separate sales function with the function of providing credit, also orders must be based on the purchase order, and prior to providing credit approval forged check gets first collection. While the system of internal control over accounts receivable, the company did not make the list and not sending receivable aging statement subscriptions receivable. For the company should make a list of accounts receivable aging and send a statement to the subscription receivable.

While the system of internal control over cash, the company did not conduct a physical inspection of cash with a note, either periodic or sudden. Not a list of details receiving money, and physical cash / checks are not kept in a safe place (safe). Therefore the company should always perform a physical examination with a cash account, whether periodical or sudden, make a list of the details of the receipt of money, and keep physical money / checks in a safe place (safe).
\end{abstract}

Keywords : Internal Control System, Security, Company Property 


\section{LATAR BELAKANG}

Sejalan dengan perkembangan manusia, maka semakin bertambah kebutuhankebutuhan untuk mempertahankan hidup dan untuk mendapatkan kehidupan yang lebih layak, maka manusia berusaha dengan berbagai cara untuk memenuhi kebutuhan tersebut. Tanda-tanda itu dapat dilihat dengan semakin berkembangnya perekonomian dunia, bertambah majunya teknologi, pendidikan dan sebagainya.

Perkembangan perekonomian dunia ditandai dengan semakin banyaknya perusahaanperusahaan yang timbul maupun berkembang menjadi perusahaan besar. Pada tahap-tahap permulaan, perusahaan yang cukup dikelola oleh seoarang pimpinan atau manajer dengan pengawasan dan sistem pencatatan yang masih sederhana, karena segala sesuatu yang terjadi dapat langsung diketahui. Dengan berkembangnya perusahaan, maka persoalan yang dihadapi akan menjadi semakin kompleks, dengan demikian pimpinan akan kurang mampu mengendalikan perusahaan dengan cara-cara sebelumnya. Untuk hal tersebut diperlukan suatu sistem pengendalian yang efektif sesuai dengan kebutuhan dan keadaan perusahaan yang dipimpinnya.

Dapat dikatakan bahwa semua perusahaan membutuhkan suatu pencatatan baik secara sederhana maupun lengkap, karena manusia mempunyai kemampuan yang terbatas untuk mengingat-ingat semua persoalan yang timbul dalam suatu perusahaan. Untuk melaksanakan semuanya itu diperlukan suatu manajemen yang baik. Salah satu fungsi dari manajemen yang menunjang keberhasilan suatu perusahaan adalah adanya pengendalian terhadap aktivitas perusahaan. Dalam perusahaan yang kecil, pemimpin dapat langsung mengawasi setiap kegiatan yang tidak sesuai dengan kebijaksanaan perusahaan dapat segera diambil tindakan koreksi. Tetapi pada perusahaan besar sangat sulit untuk melakukannya, maka seorang pemimpin harus melakukan pendelegasian wewenang atau pembagian tugas kepada orang lain. Pendelegasian ini dimaksud agar kegiatan perusahaan dapat berjalan lancar sesuai dengan kebijaksanaan yang digariskan perusahaan.

Dengan adanya pendelegasian wewenang dan tugas, manajemen memerlukan suatu sistem pengendalian yang memastikan bahwa setiap karyawan telah melakukan pekerjaan sesuai dengan wewenang dan tugasnya sehingga perusahaan dapat mengamankan harta perusahaan, yang pada akhirnya tujuan dari perusahaan yaitu untuk memperoleh laba yang sebesar-besarnya dapat terpenuhi targetnya. Adanya pengendalian intern yang baik dalam sutau perusahaan, antara lain :

1. Memperkecil kemungkinan kesalahan dalam pembukuan, sehingga dapat menghasilkan laporan keuangan yang akurat.

2. Mengurangi kemungkinan terjadinya kecurangan dalam perusahan.

3. Memberikan keyakinan bahwa kebijaksanaan-kebijaksanaan perusahaan yang diterapkan telah dijalankan sebagaimana mestinya.

4. Menghasilkan kerja yang efesien sehingga pemborosan dapat dihindari..

Pengendalian intern atas penjualan penting untuk mengawasi seluruh hasil pendapatan dan penjualan perusahaan, agar dapat dicapai jumlah hasil pengembalian yang semaksimal mungkin atas investasi. Pendapatan perusahaan dari penjualan dapat diperoleh dari hasil penjualan tunai dan penjualan kredit. Salah satu cara perusahaan untuk menguasai pasar adalah dengan menyediakan fasilitas melalui penjualan kredit. Dengan melakukan penjualan kredit diharapkan total penjualan akan meningkat. Dilain pihak akan timbul piutang dagang yang memerlukan penanganan dan pengelohan yang baik dan terarah, sebab piutang merupakan salah satu harta lancar dalam perusahaan. 
Penerimaan uang dari penjualan tunai dan penagihan atas piutang dari penjualan kredit atau menghasilkan uang tunai yang dengan mudah dapat menjadi sasaran kecurangan atau manipulasi yang dapat mengakibatkan kerugian bagi perusahaan. Oleh karena itu penting bagi perusahaan untuk mengendalikan penjualan, penerimaan kas, karena pengendalian manajemen merupakan jalan terbaik untuk menurunkan biaya maupun kemungkinan penyelewengan yang terjadi.

\section{Kerangka pemikiran}

Pengendalian intern dalam suatu perusahaan merupakan faktor yang terpenting, dimana perusahaan dalam kegiatannya selalu menitikberatkan pengendalian karena perusahaan beranggapan bahwa pengendalian intern merupakan tolak ukur keberhasilan suatu perusahaan. Untuk itu perusahaan harus lebih memperhatikan cara yang terbaik dalam menetapkan manajemen yang baik supaya tujuan perusahaan dapat dicapai. Dengan terjaminnya pengendalian yang baik, maka akan menjamin aktivitas perusahaan yang selain memberikan kepuasan kepada para pelanggan, juga akan dirasakan oleh perusahaan tentang pengendalian intern yang baik dan bermanfaat bagi perusahaan.

\section{TELAAH LITERATUR DAN PENGEMBANGAN HIPOTENSI}

\subsection{Pengertian, Tujuan, Unsur dan Fungsi Pengendalian Intern}

Dalam perusahaan yang masih belum berkembang, pengelolaan perusahaan baik untuk pengawasan operasional maupun akuntansinya masih dapat ditangani oleh seorang pimpinan. Tetapi apabila perusahaan tersebut semakin besar, maka pimpinan perusahaan tidak lagi dapat melaksanakan segala sesuatunya sendiri dan harus melakukan pendelegasian wewenang, untuk itu diperlukan suatu sistem untuk mengendalikan kegiatan-kegiatan tersebut, salah satu diantaranya adalah sistem pengendalian intern.

Pengertian pengendalian intern menurut Ikatan Akuntan Indonesia (1995 : PSAK No.12) didefinisikan sebagai berikut : "Pengendalian (control) adalah wewenang (power) untuk mengatur dan menentukan kebijakan keuangan dan operasi dari suatu kegiatan usaha dengan tujuan untuk mendapatkan manfaat dari kegiatan tersebut" Pengertian pengendalian intern ini disamakan dengan manajemen control, yang meliputi semua cara yang digunakan oleh pimpinan perusahaan untuk mengawasi atau mengendalikan perusahaan. Definisi dari pengendalian intern ini makin lama makin berkembang. Menurut Ruchyat Kosasih (2002 : 113), pengendalian dapat dibagi menjadi :

1. Administrasi Control

Meliputi rencana organisasi serta prosedur dan catatan yang berhubungan dengan proses pembuatan keputusan yang akan menyebabkan pimpinan perusahaan untuk menyetujui atau memberi wewenang atas terjadinya transaksi-transaksi. Pemberian wewenang ini merupakan fungsi pimpinan perusahaan yang secara langsung berhubungan dengan tanggungjawab mencapai tujuan perusahaan.

2. Accounting Controls

Meliputi rencana organisasi serta prosedur-prosedur dan catatan-catatan yang berhubungan dengan keamanan kekayaan perusahaan dan dapat dipercayainya catatancatatan keuangan, oleh karena itu disusun sedemikian rupa untuk meyakinkan bahwa :

a. Transaksi dilaksanakan sesuai dengan otorisasi manajemen yang khusus atau umum.

b. Transaksi dicatat sedemikian rupa sehingga memungkinkan dibuatnya :

- Laporan keuangan sesuai dengan prinsip-prinsip akuntansi yang lazim. 
- Meyelenggarakan pertanggungjawaban aktiva.

- Pemindahan hak atas aktiva hanya diperkenankan sesuai dengan persetujuan atau wewenang pimpinan.

- Pertanggungjawaban aktiva yang dicatat dibandingkan dengan aktiva yang ada dengan selang waktu yang memadai dan tindakan yang tepat dilakukan bila terjadi perbedaan atau biasa disebut dengan "Principal By Exception".

Berdasarkan dari pengertian dan definisi dari pengendalian intern yang dibahas di atas maka dapat dimengerti bahwa tujuan dari pengendalian intern yang dilakukan perusahaan yaitu untuk mengamankan aktiva-aktiva terhadap kerugian-kerugian yang dapat terjadi akibat kesalahan yang disengaja atau yang tidak disengaja serta menghasilkan laporan-laporan keuangan yang dapat dipercaya untuk tujuan pelaporan extern dan intern.

Tujuan yang hendak dicapai dari pengendalian intern adalah :

1. Menyediakan data-data yang dapat diandalkan

2. Mengamankan harta dan catatan-catatan perusahaan

3. Meningkatkan efesiensi operasi

4. Mendorong ditaatinya kebijaksanaan yang telah ditetapkan.

Sedangkan tujuan pengendalian intern menurut mulyadi (2004 : 47) sebagai berikut :

1. Menjaga kekayaan organisasi

2. Mengecek ketelitian dn dapat dipercaya tidaknya data akuntansi

3. Mendorong efesiensi

4. Mendorong ditaati kebijaksanaan manajemen

Keempat tujuan pengendalian intern diatas sangat bermanfaat bagi para manajemen dalam menjalankan perusahaan, karena dalam mengambil suatu keputusan mereka berpedoman pada informasi yang terkandung dalam laporan yang mereka terima. Untuk itu suatu pengendalian intern yang baik akan memberikan keuntungan yang besar bagi perusahaan antara lain :

1. Memperkecil kemungkinan kesalahan-kesalahan dalam menyajikan data-data akuntansi sehingga akan menghasilkan laporan akurat dan dapat dipercaya.

2. Membatasi kemungkinan manipulasi

3. Menghasilkan tingkat efisiensi yang lebih tinggi.

4. Mendorong ditaatinya kebijaksanaan pimpinan yang telah digariskan.

Pengendalian intern suatu perusahaan tidak selalu dapat diterapkan pada perusahaan lain, walaupun perusahaan tersebut bergerak dalam bidang yang sama, karena setiap perusahaan memiliki cirri khasnya masing-masing. Perbedaan tersebut adalah dari besar kecilnya perusahaan, struktur organisasi, kebijakan maupun keahlian dari pimpinannya.

Adapun syarat-syarat yang harus dipenuhi pada sistem internal control yang berbeda-beda, agar segala sesuatu yang berupa kemungkinan-kemungkinan yang dapat merugikan perusahaan dapat dihindarkan. Elemen pokok untuk mencapai suatu internal control yang memadai dan memuaskan ialah :

1. Suatu struktur organisasi yang memisahkan tanggungjawab fungsional secara tepat.

2. Suatu sistem wewenang dan prosedur pembukuan yang baik, yang berguna untuk melakukan pengawasan akuntansi yang cukup terhadap harta milik, utang, pendapatan dan biaya-biaya.

3. Praktek-praktek yang sehat dan fungsi-fungsi setiap bagian dalam organisasi.

4. Karyawan yang mutunya sesuai dengan tanggungjawab. 


\section{METODOLOGI PENELITIAN}

\subsection{Metode Penelitian}

Metodelogi penelitian yang dipakai dalam pengumpulan data untuk menyusun skripsi ini adalah metode deskriptif (pemaparan), yaitu menjelaskan bagaimana pelaksanaan pengendalian intern pada CV. Kencana Jaya Bandar Lampung, maka digunakan :

\section{Pengumpulan Data}

Metode pengumpulan data merupakan suatu kegiatan pengumpulan data, penyajian dan analisa data yang dilakukan dengan metode ilmiah dan sistematis, yang hasilnya berguna untuk mengetahui suatu keadaan atau persoalan dan untuk membuat keputusan dalam rangka memecahkan masalah. Adapun metode pengumpulan data yang digunakan :

\section{Studi Kepustakaan (Library Research)}

Studi kepustakaan dimaksudkan untuk mengumpulkan bahan-bahan dan dasar teori yang cukup dalam menjalankan pengendalian intern sebagai penunjang untuk menyusun skripsi ini.

\section{Penelitian Lapangan}

Penelitian lapangan ini dapat dilakukan dengan cara sebagai berikut:

a. Observasi,

Observasi adalah pengamatan secara langsung terhadap suatu objek. Adapun yang diamati adalah sistem penjualan dan piutang dalam rangka mendapatkan data-data berupa :

1. Data sistem pengendalian penjualan

2. Data sistem pengendalian piutang

b. Wawancara

Wawancara adalah tanya jawab kepada pihak-pihak yang berhubungan dengan penulisan skripsi. Adapun pihak-pihak yang dimaksud adalah bagian penjualan dan piutang ( 2 orang), dalam rangka mendapatkan data-data :

1. Penjualan

2. Piutang usaha, piutang tak tertagih dan piutang yang telah dihapus

\section{Jenis dan Sumber Data} skunder.

Data yang dipergunakan dalam penelitian ini bersumber dari data primer dan data

a. Data Primer

Data Primer Yaitu data penelitian yang diperoleh dari objek penelitian atau perusahaan

b. Data Skunder

Data Skunder Yaitu data penelitian yang diperoleh dari pihak diluar perusahaan yaitu brosur-brosur, peraturan dan tulisan lainnya yang erat kaitannya dengan masalah yang diteliti.

\subsection{Metode Analisis}

Metode analisis yang dipergunakan dalam penyusunan skripsi ini adalah analisa deskriptif kualitatif, sehingga dapat diketahui seberapa jauh perbedaannya. Dengan analisis 
perbadingan diharapkan permasalahan itu akan terjawab dan hasil analisa digunakan untuk mengambil kesimpulan dan saran-saran yaitu analisis yang digunakan dengan cara membandingkan teori yang relevan dengan kenyataan-kenyataan yang ada pada perusahaan.

\section{HASIL DAN PEMBAHASAN}

\subsection{Sistem Pengendalian Intern Perusahaan}

\section{a. Sistem Pengendalian Intern Penjualan}

Penjualan merupakan sarana bagi perusahaan dalam mencapai tujuannya, yaitu memperoleh laba untuk kelangsungan hidup perusahaan.

\section{b. Struktur organisasi}

Struktur organisasi merupakan unsure yang penting artinya dalam menerapkan suatu sistem internal control yang baik. Struktur organisasi merupakan kerangka pembagian tanggung jawab fungsional kepada unit-unit organisasi yang dibentuk untuk melaksanakan kegiatan-kegiatan perusahaan. Setiap perusahaan harus mempunyai struktur organisasi yang sesuai denagn perusahaan tersebut. Sifat perusahaan, besar kecilnya perusahaan, penyeberan daerah operasi secara geografis, jumlah anak perusahaan dan lain-lain dapat mempengaruhi struktur organisasi. Umumnya struktur organisasi harus sederhana, agar tercipta kegaitan yang ekonomis, tidak kaku agar perluasan ataupun perubahan kondisi tidak menimbulkan reorganisasi struktur secara keseluruhan. Adapun batas yang jelas dalam wewenang dan tanggung jawab, yang terwujud dalam pemisahan fungsi :

- Yang berhak memberikan otorisasi

- Fungsi operasi/pelaksanaan

- Fungsi penyimpanan

- Fungsi pencatatan

- Fungsi pengawasan

Merupakan syarat untuk mencapai sistem pengendalian intern yang memadai. Sehingga dengan pemisahan fungsi ini, tidak ada satu bagianpun dalam perusahaan yang melaksanakan suatu transaksi dari awal sampai akhir tanpa campur tangan bagian lainnya. Hal ini dimaksudkan untuk memungkinkan adanya saling pengecekan antar bagian yang berfungsi untuk mencegah terjadinya penyelewengan. Jadi berhasil atau tidaknya suatu struktur organisasi tergantung bagaimana orangnya, apakah jujur, cakap, ahli dan sebagainya. Sebagaimana telah dijelaskan dalam bab sebelumnya pada CV. Kencana Jaya tidak memiliki fungsi yang akan memberikan kredit dengan bagian penjualan (fungsi kredit telah menyatu dengan bagian penjualan). Adapun struktur organisasi penjualan (bagian-bagian yang ada diorganisasi penjualan) adalah sebagai berikut :

- Pesanan penjualan, yang bertugas menerima pesanan dan langganan/ konsumen.

- Bagian kredit, yang bertugas memberikan/menolak suatu kredit

- Bagian pengiriman barang, yang bertugas memberikan/menolak suatu kredit

- Bagian pengiriman barang, yang bertugas mengirim suatu pesanan kepada pemesan.

- Bagian pembuatan faktur, yang bertugas membuat faktur penjualan. 


\section{c. Prosedur Pencatatan}

CV. Kencana Jaya melakukan penjualan secara tunai maupun secara kredit. Salah satu cara perusahaan untuk menguasai pasar adalah dengan menyediakan fasilitas penjualan kredit dengan harapan kemungkinan penjualan total akan meningkat. Fasilitas pemberian kredit pada langganan diberikan langsung oleh bagian penjualan tanpa melalui pemeriksaan lebih lanjut terhadap kemampuan langganan dalam melunasi hutangnya ataupun menghubungi bagian penagihan untuk mendapatkan informasi mengenai kredit langganan yang bersangkutan. Para salesman sebagai ujung tombak perusahaan dalam melakukan penjualan mencatat hasil penjualannya langsung dicatat dibukunya tanpa adanya formulir sales order sebagai bukti pengakuan telah diterimanya order pembelian dari langganan. Order pemesanan dari langganan sering kali pemenuhan pesanannya melalui telpon tidak didasarkan pada order pembelian dari langganan secara tertulis sehingga sering terjadi kesalahan dalam menerima pesanan atau barang yang dikirim tidak sesuai dengan pesanan.

\section{d. Prosedur pencatatan}

Prosedur penjualan yang dilakukan oleh CV. Kencana Jaya adalah sebagai berikut :

1. Pesanan pembelian dari langganan dapat melalui telpon, faxcimile, surat. Apabila pesanan langsung melalui telpon, maka dapat dibicarakan langsung mengenai harga, jenis barang, jumlah barang, dan syarat pembayarannya. Sedangkan untuk pesanan yang melalui faxcimile dan surat terlebih dahulu bagian penjualan harus memeriksa data-data di dalamnya sebelum pesanan diterima. Apabila ada yang tidak disetujui atau ada barang yang persediaanya kurang, harus segera mengabari langganan yang bersangkutan. Apabila telah disetujui maka pembeli yang memesan lewat telpon dapat segera mengirim order pembelian ke kantor. Atas dasar order pembelian dari langganan yang telah disetujui, bagian penjualan membuat delivery order dalam rangkap tiga. Delivery order diparaf oleh bagian penjualan dan ditanda tangani oleh pejabat yang berwenang mengeluarkan barang dari gudang. Tampa tanda tangan yang berwenang, bagian gudang tidak dapat mengeluarkan barang dari dalam gudang. Setelah ditanda tangani, delivery order lembar kesatu dan lembar kedua dikirim ke gudang. Sedangkan lembar ketiga diarsip oleh bagian penjualan. Oleh bagian gudang berdasarkan delivery order yang diterima dari bagian penjualan membuat surat jalan rangkap empat. Pada saat pengiriman barang, langganan dimintai tanda tangan pada surat jalan yang bersangkutan sebagai bukti telah diterimanya barang pesanannya. Kemudian surat jalan lembar kedua diberikan kepada pembeli. Bagian gudang mengarsipkan delivery order lembar kedua dan surat jalan lembar keempat. Delivery order kesatu dan surat jalan lembar kesatu dan ketiga dibawa kekantor dan didistribusikan sebagai berikut :

Delivery order lembar 1 - bagian akuntansi

Lembar 2 - bagian gudang

Lembar 3 - bagian penjualan

2. Berdasarkan surat jalan lembar kesatu yang diterima dari gudang, bagian penjualan membuat faktur penjualan rangkap empat, diparaf oleh bagian penjualan. Kemudian faktur penjualan dibawa kebagian penagihan. Bagian penjualan melakukan pengecekan baik mengenai perhitungan maupun kelengkapan dokumen pendukung/lampirannya. Apabila telah cocok maka faktur penjualan ditanda tangani oleh manajer penjualan kemudian siap untuk dikirim kepada pembeli. Demikianlah prosedur penjualan yang dilakukan CV. Kencana Jaya. Terlihat dari prosedur penjualannya pemisahan antara fungsi penjualan yang melakukan penjualan, fungsi gudang yang mengeluarkan barang 
dan fungsi akuntansi yang mencatat transaksi penjualan serta fungsi penagihan yang melakukan penagihan ke langganan, pemisahan fungsi tersebut dimaksudkan agar di dalam melakukan transaksi penjualan dari awal sampai akhir hanya dilakukan oleh satu orang saja sehingga dapat mencegah terjadinya kecurangan atau penyimpangan di dalam perusahaan.

Pengendalian intern atas CV. Kencana Jaya cukup baik seperti terlihat pada hal - hal dibawah ini:

a. Adanya pemakai formulir/dokumen yang bernomor urut tercetak dan pemakaiannya dipertanggung jawabkan yaitu dengan adanya otorisasi atau tanda tangan pada formulir yang digunakan.

b. Adanya formulir/dokumen yang dibuat secara rangkap sehingga dapat mencegah atau mengurangi penyelewengan dan kecurangan.

c. Adanya pemisahan dari fungsi yang jelas yaitu fungsi penjualan terpisah dari fungsi akuntansi, fungsi penagihan, gudang sehingga dapat menciptakan pengecekan silang.

\subsection{Sistem Pengendalian Intern Piutang}

\section{a. Struktur Organisasi}

Pada CV. Kencana Jaya, bagian penjualan sering menyetujui pesanan dari langganan tersebut tanpa melihat terlebih dahulu apakah debitur memiliki tunggakan pembayaran atau tidak. Akibat tidak terdapatnyapemisahan bagian yang akan memberi kredit dengan bagian penjualan memungkinkan penjualan kredit yang diberikan kepada pembeli/ langganan yang tidak bonafide dapat menyebabkan kemungkinan piutang tak tertagih sehingga menimbulkan piutang ragu-ragu. Timbulnya saldo yang cukup besar atas piutang ragu akan menggangu arus kas perusahaan. Dengan terganggunya arus kas perusahaan dapat mengakibatkan banyak hal yang negative dimana perusahaan dapat dicap sebagai perusahaan yang kreditnya macet. Hal ini kemudian hari akan mengakibatkan perusahaan kesulitan dalam mendapatkan kredit apabila memerlukannya. Adapun unit yang ada dalam organisasi piutang ialah bagihan penagihan yang bertugas melakukan penagihan atas piutang yang telah jatuh tempo maupun yang menunggak.

\section{b. Prosedur Pencatatan}

Dalam melakukan penjualan kredit perusahaan mencatat dalam buku piutang. Bila langgann ingin mengetahui jumlah hutangnya kepada perusahaan, perusahaan akan memberitahukan kepada langganan melalui salesman. Perusahaan tidak menyelenggarakan daftar umur piutang menurut umurnya sehingga tidak dapat diketahui piutang mana yang kemungkinan dapat tak tertagih dan dapat tertagih.

\section{c. Formulir dan Pencatatan}

Prosedur pencatatan piutang CV. Kencana Jaya sebagai berikut :

1. Setelah faktur penjualan ditanda tangani oleh manajer penjualan, oleh bagihan penagihan faktur penjualan beserta lampirannya yaitu order pembelian dari langganan oleh kolektor yang merupakan bagian dari penagihan. Bagian penagihan melakukan pencatatan piutang langganan yang bersangkutan ke kartu piutang langganan tersebut.

2. Untuk faktur penjualan yang akan dibawa oleh kolektor dicatat terlebih dahulu oleh bagian penagihan ke dalam suatu catatan perincian mengenai faktur penjualan yang dibawa oleh kolektor untuk ditagih ke langganan pada hari yang bersangkutan. 
3. Kolektor yang telah menyelesaikan tugasnya, menyerahkan tanda terima dari langganan kepada bagian penagihan. Bagian penagihan mencocokan dulu faktur penjualan yang dibawa oleh kolektor pada hari tersebut apakah telah ditukar dengan tanda terima dari langganan dengan melihat catatan perincian faktur penjualan yang dibawa.

Oleh bagian akuntansi, jumlah faktur penjualan yang terjadi salama satu hari dicatat dalam buku jurnal yang kemudian diposting ke rekening control piutang dalam buku besar. Pada setiap akhir bulan, diadakan rekonsiliasi antara saldo kartu piutang dengan rekening control piutang dalam buku besar. Denagn adanya rekonsiliasi tersebut maka apabila terjadi perbedaan dapat dicari kesalahannya.

Untuk tagihan yang mengalami kesulitan, bagian penagihan dapat meminta bantuan dari bagian penjualan untuk mengatasi terdapatnya piutang tak tertagih. Apabila suatu tagihan yang dianggab tidak dapat titagih kembali, maka piutang tersebut dihapuskan melalui persetujuan dari direktur. Untuk menampung kemungkinan tak tertagihnya suatu piutang, amak perusahaan membentuk perkiraan cadangan piutang ragu-ragu.

Dalam melakukan penjualan kredit, perusahaan mencatat dalam buku piutang. Bila langganan ingin mengetahui jumlah hutangnya kepada perusahaan, perusahaan akan memberitahukan kepada langganan melalui salesman. Perusahaan tidak menyelenggarakan daftar umur piutang menurut umurnya, sehingga tidak dapat diketahui piutang mana yang kemungkinan dapat tak tertagih dan dapat tertagih.

\subsection{Sistem Pengendalian Intern Kas}

Kas merupakan aktiva lancar yang sangat rawan atas tindakan penyalahgunaan serta merupakan perkiraan yang paling likuid dan penting bagi setiap perusahaan

\section{a. Struktur Organisasi}

Adapun struktur organisasi penerimaan kas adalah sebagai berikut :

1. Bagian kasir, yang bertugas menerima dan mengeluarkan uang (pengeluaran yang bersifat kecil).

2. Bagian penerimaan surat masuk, yang bertugas menerima bukti adanya kas yang masuk/penerimaan kas.

\section{Prosedur Pengendalian Kas}

Uang kas disimpan pada satu tangan yaitu kasir, dimana pemeriksaan jumlah uang kas dilakukan satu kali dalam satu bulan. Cek atau giro yang diterima dari langganan langsung dimasukkan kedalam brangkas dan setiap hari dikeluarkan guna melihat tanggal jatuh temponya untuk dikliring di bank tanpa dibuat daftar perinciannya.

\section{b. Formulir dan Pencatatannya}

Penerimaan kas dapat berasal dari berbagai sumber, seperti dari pelunasan piutang, setoran pemilik modal dan lain-lain. Yang akan dibahas disini adalah penerimaan kas yang berasal dari pelunasan piutang.

1. Bagian penagihan menghubungi langganan yang tagihannya telah jatuh tanpa melalui telpon.

2. Untuk tagihan yang sudah biasa diambil, bagian penagihan membuat catatan rincian tagihan yang akan dibawa untuk ditagih. Kemudian menyerahkan tanda terima tersebut kepada kolektor yang melakukan penagihan kepada langganan. 
3. Uang tunai, cek/bilyet giro yang diterima dari langganan diserahkan ke bagian penagihan untuk dicatat pelunasannya pada bukti pelunasan piutang yang bernomor urut tercetak dan dibuat dalam rangkap dua yang didistribusikan sebagai berikut :

Bukti pelunasan piutang lembar 1 : Bagian akuntansi

lembar 2 : arsip

4. Uang tunai, cek/giro yang didapat dari hasil penagihan diserahkan kekasir, kemudian kasir mengecek apakah ada giro yang sudah jatuh tempo. Giro yang jatuh tempo keesokan harinya yang oleh kasir dicatat dulu kedalam buku agenda harian menurut tanggal jatuh tempo.

5. Membuat laporan harian kas/bank atas penerimaan dan penyetoran uang/cek/giro ke bank pada hari itu dan menyerahkannya ke bagian akuntansi beserta lampiranlampirannya (bukti setoran yang sudah dicap oleh bank).

6. Bagian akuntansi mencatat pelunasan piutang ke dalam jurnal dan diposting ke buku besar berdasarkan bukti pelunasan piutang dari bagian penagihan.

7. Setiap akhir bulan dibuat rekonsiliasi bank untuk mencocokan saldo menurut buku bank dengan rekening Koran oleh bagian akuntansi.

\subsection{Analisis Data}

\section{Analisis Sistem Pengendalian Intern atas Penjualan}

Secara umum, prosedur penjualan digunakan untuk mengawasi apakah semua pesanan yang diterima telah diselesaikan dengan tepat pada waktunya. Disamping itu juga untuk memastikan bahwa semua factor penjualan telah dicatat dengan benar dan tepat. Adapun dokumen dan formulir yang digunakan dalam melakukan transaksi penjualan adalah sebagai berikut :

a. Order pembelian

Order pembelian ini diterima dari langganan yang memesan barang ke CV. Kencana Jaya. Dengan dasar order pembelian ini, perusahaan menjual barang kepada pembeli.

Dalam order pembelian umumnya tercamtum :

- Kuantitas/jumlah barang yang diperlukan

- Jenis barang

- Harga barang

- Syarat pembayaran

- Tempat pengiriman barang

- Jangka waktu penerimaan barang

b. Delivery order

Merupakan suatu dokumen/formulir untuk pengeluaran barang dari gudang untuk kemudian dikirim kepada pembeli yang bersangkutan.

Delivery order dibuat dan diparaf oleh bagian penjualan dan ditanda tangani pejabat yang berwenang untuk mengeluarkan barang dari gudang.

Berdasarkan delivery order ini, bagian gudang baru berhak untuk mengeluarkan barang. Dalam delivery order tercantum hal-hal sebagai berikut :

- Nama pembeli

- Nama barang yang diperlukan

- Kuantitas/jumlah barang 
Delivery order ini dibuat dalam rangkap tiga dan didistribusikan sebagai berikut :

Delivery order Lembar 1: bagian akuntansi

Lembar 2 : bagian gudang

Lembar 3 : arsip bagian penjualan

c. Surat jalan

Merupakan suatu dokumen/formulir yang dibuat oleh bagian gudang untuk dasar pengiriman barang. Dengan surat jalan ini, petugas pengiriman termasuk bagian gudang mengirim barang ke langganan. Petugas pengiriman kemudian meminta tanda tangan langganan yang menerima barang pada surat jalan tersebut sebagai tanda telah diterimanya barang pesanannya. Dalam surat jalan terdapat keterangan sebagai berikut :

- Nama penerima

- Alamat yang dituju

- Jumlah barang yang dikirim

- Nama barang yang dikirim

- Nomor plat polisi kendaraan yang dipakai untuk mengirim barang

- Nomor delivery order.

Surat jalan ini dibuat dalam rangkap 4 (empat) dan didistribusikan sebagai berikut:

Surat jalan lembar 1 - penjualan

lembar 2 - pembeli/langganan

lembar 3 - bagian akuntansi

lembar 4 - arsip bagian gudang

d. Faktur penjualan

Merupakan suatu dokumen/formulir tagihan kelangganan yang dibuat oleh bagian penjualan. Adapun keterangan-keterangan yang tercamtum dalam faktur penjualan adalah sebagai berikut :

- nama dan alamat pembeli

- Nama barang yang dijual

- Harga satuan

- Kuantitas/jumlah barang dijual

- Jumlah discount yang diberikan (kalau ada)

Faktur penjualan ini dibuat dalam rangkap empat dan didistribusikan sebagai berikut :

Faktur penjualan lembar 1 : pembeli

lembar 2 : bagian akuntansi

lembar 3 : bagian penagihan

lembar 4 : arsip bagian penjualan

e. Prosedur penjualan

Prosedur penjualan yang dilakukan oleh CV. Kencana Jaya adalah sebagai berikut:

a. Pesanan pembelian dari langganan dapat melalui telpon, faxcimile, surat. Apabila pesanan langsung melalui telpon, maka dapat dibicarakan langsung mengenai harga, jenis barang, jumlah barang, dan syarat pembayarannya. Sedangkan pembayaran yang melalui faxcimile dan surat terlebih dahulu bagian penjualan harus memeriksa data-data di dalamnya sebelum pesanan diterima. Apabila ada yang tidak disetujui atau ada barang yang persediaanya kurang, harus segera mengabari langganan yang bersangkutan. Apabila telah disetujui maka pembeli yang memesan lewat telpon dapat segera mengirim order pembelian ke kantor. Atas dasar order pembelian dari langganan yang telah disetujui, bagian penjualan membuat delivery order dalam 
rangkap tiga. Delivery order diparaf oleh bagian penjualan dan ditanda tangani oleh pejabat yang berwenang mengeluarkan barang dari gudang. Tampa tanda tangan yang berwenang, bagian gudang tidak dapat mengeluarkan barang dari dalam gudang. Setelah ditanda tangani, delivery order lembar kesatu dan lembar kedua dikirim ke gudang. Sedangkan lembar ketiga diarsip oleh bagian penjualan.

Oleh bagian gudang berdasarkan delivery order yang diterima dari bagian penjualan membuat surat jalan rangkap empat. Pada saat pengiriman barang, langganan dimintai tanda tangan pada surat jalan yang bersangkutan sebagai bukti telah diterimanya barang pesanannya. Kemudian surat jalan lembar kedua diberikan kepada pembeli.

Bagian gudang mengarsipkan delivery order lembar kedua dan surat jalan lembar keempat. Delivery order kesatu dan surat jalan lembar kesatu dan ketiga dibawa kekantor dan didistribusikan sebagai berikut:

Delivery order lembar 1 - bagian akuntansi

lembar 2 - bagian gudang lembar 3 - bagian penjualan

b. Berdasarkan surat jalan lembar kesatu yang diterima dari gudang, bagian penjualan membuat faktur penjualan rangkap empat, diparaf oleh bagian penjualan. Kemudian faktur penjualan dibawa kebagian penagihan. Bagian penjualan melakukan pengecekan baik mengenai perhitungan maupun kelengkapan dokumen pendukung/lampirannya. Apabila telah cocok maka faktur penjualan ditanda tangani oleh manajer penjualan kemudian siap untuk dikirim kepada pembeli.

Demikianlah prosedur penjualan yang dilakukan CV. Kencana Jaya. Terlihat dari prosedur penjualannya pemisahan antara fungsi penjualan yang melakukan penjualan, fungsi gudang yang mengeluarkan barang dan fungsi akuntansi yang mencatat transaksi penjualan serta fungsi penagihan yang melakukan penagihan ke langganan, pemisahan fungsi tersebut dimaksudkan agar di dalam melakukan transaksi penjualan dari awal sampai akhir hanya dilakukan oleh satu orang saja sehingga dapat mencegah terjadinya kecurangan atau penyimpangan di dalam perusahaan. Pengendalian intern atas CV. Kencana Jaya cukup baik seperti terlihat pada hal - hal dibawah ini :

- Adanya pemakai formulir/dokumen yang bernomor urut tercetak dan pemakaiannya dipertanggung jawabkan yaitu dengan adanya otorisasi atau tanda tangan pada formulir yang digunakan.

- Adanya formulir/dokumen yang dibuat secara rangkap sehingga dapat mencegah atau mengurangi penyelewengan dan kecurangan.

- Adanya pemisahan dari fungsi yang jelas yaitu fungsi penjualan terpisah dari fungsi akuntansi, fungsi penagihan, gudang sehingga dapat menciptakan pengecekan silang.

Namun demikian juga terdapat kelemahan-kelemahan sebagai berikut :

- Perangkapan fungsi penjualan dengan fungsi pemberian kredit kepada langganan dapat mengakibatkan keadaan yang merugikan dimana bagian penjualan dapat memanfaatkan kesempatan ini dengan melakukan penjualan dengan cara memberikan persetujuan kredit kepada langganan tanpa melakukan seleksi/pemeriksaan lebih lanjut. Ini dapat mengakibatkan piutang yang tidak tertagih meningkat jika langganan tidak mampu melunasi hutangnya. Jadi hal ini sangat merugikan perusahaan. 
- Tidak diselenggarakan formulir sebagai bukti pengakuan telah diterimanya order pembelian dari langganan.

- Seringkali tertulis pemenuhan pesanan melalui telpon tidak berdasarkan pada order pembelian dari langganan secara tertulis sehingga sering terjadi kesalahan dalam menerima pesanan tersebut.

Penulis memberikan saran sebagai berikut :

a. Sebaiknya sebelum pesanan langganan dipenuhi, bagian penjualan harus mengecek terlebih dahulu piutang langganan yang tersangkut ke bagian penagihan. Dengan demikian dihindari terdapatnya piutang yang tak tertagih yang dapat merugikan perusahaan.

b. Sebaiknya diselenggarakan formulir sales order sebagai bukti pengakuan telah diterimanya order pembelian dari langganan.

c. Penerima pesanan dari langganan melalui telpon harus dilanjutkan dengan pengiriman order pembelian dari langganan secara tertulis. Ini untuk menghindari kesalahan penerimaan pesanan langganan yang dapat mengakibatkan pengeluaran biaya yang tidak efesien.

\section{Analisis Sistem Pengendalian Intern atas Piutang.}

Piutang timbul karena adanya transaksi penjualan kredit. Piutang merupakan bagian dari aktiva lancer yang dapat digolongkan dalam perkiraan yang sangat penting dalam neraca. Piutang sering menjadi sasaran kecurangan atau penggelapan karena piutang melalui penagihannya dapat menghasilkan uang.

Selain itu piutang dapat juga tidak tertagih yang mungkin dikarenakan langganan bangkrut atau hal lain yang menyebabkannya. Oleh karena itu sangat diperlukan pengendalian intern yang memadai atas piutang perusahaan sehingga dapat diharapkan semua piutang dapat tertagih. Disamping itu juga untuk mencegah atau mengurangi kecurangan atau penyelewengan yang dapat terjadi pada waktu penagihan piutang.

Penjualan kredit yang diberikan kepada pembeli/langganan yang tidak bonafit dapat menyebabkan kemungkinan piutang tak tertagih sehingga menimbulkan piutang ragu-ragu. Timbulnya saldo yang cukup besar atas piutang ragu akan menggangu arus kas perusahaan. Dengan terganggunya arus kas perusahaan dapat mengakibatkan banyak hal yang negative dimana perusahaan dapat dicap sebagai perusahaan yang kreditnya macet. Hal ini kemudian hari akan mengakibatkan perusahaan kesulitan dalam mendapatkan kredit apabila memerlukannya.

Pengendalian intern yang memadai atas piutang sebenarnya dimulai sebelum adanya persetujuan pengiriman barang dagangan sampai penyimpangan faktur penjualan dan penagihan hasil penjualan. Pada CV. Kencana Jaya, bagian penjualan sering menyetujui pesanan dari langganan tersebut terdapat tunggakan pembayaran atau tidak.

Sebelum membahas pengendalian intern atas piutang, terlebih dahulu akan dibahas prosedur pitang sebagai berikut :

a. Setelah faktur penjualan ditanda tangani oleh manajer penjualan, oleh bagihan penagihan faktur penjualan beserta lampirannya yaitu order pembelian dari langganan oleh kolektor yang merupakan bagian dari penagihan. Bagian penagihan melakukan pencatatan piutang langganan yang bersangkutan ke kartu piutang langganan tersebut.

b. Untuk faktur penjualan yang akan dibawa oleh kolektor dicatat terlebih dahulu oleh bagian penagihan ke dalam suatu catatan perincian mengenai faktur penjualan yang dibawa oleh kolektor untuk ditagih ke langganan pada hari yang bersangkutan. 
c. Kolektor yang telah menyelesaikan tugasnya, menyerahkan tanda terima dari langganan kepada bagian penagihan. Bagian penagihan mencocokan dulu faktur penjualan yang dibawa oleh kolektor pada hari tersebut apakah telah ditukar dengan tanda terima dari langganan dengan melihat catatan perincian faktur penjualan yang dibawa.

Oleh bagian akuntansi, jumlah faktur penjualan yang terjadi salama satu hari dicatat dalam buku jurnal yang kemudian diposting ke rekening control piutang dalam buku besar. Pada setiap akhir bulan, diadakan rekonsiliasi antara saldo kartu piutang dengan rekening control piutang dalam buku besar. Dengan adanya rekonsiliasi tersebut maka apabila terjadi perbedaan dapat dicari kesalahannya. Untuk tagihan yang mengalami kesulitan, bagian penagihan dapat meminta bantuan dari bagian penjualan untuk mengatasi terdapatnya piutang tak tertagih. Apabila suatu tagihan yang dianggab tidak dapat titagih kembali, maka piutang tersebut dihapuskan melalui persetujuan dari direktur. Untuk menampung kemungkinan tak tertagihnya suatu piutang, amak perusahaan membentuk perkiraan cadangan piutang raguragu.

Berdasarkan pada prinsip pengendalian intern pada piutang, antara lain menyatakan bahwa kreditor harus mengirim surat konfirmasi piutang kepada langganansecara periodik, membuat daftar umur piutang guna mengetahui besarnya piutang perusahaan dan cadangan piutang macet. Berdasarkan perbandingan diatas terdapat kelemahan sebagai berikut :

1. Perusahaan tidak mengirimkan surat peryataan piutang kepada langganan secara periodik. Hal ini dapat mengakibatkan kemungkinan kesalahan pencatatan atas jumlah piutang antara langganan dan perusahaan. Dan kemungkinan dapat terjadi piutang yang telah lunas belum dicatat oleh perusahaan atau adanya pengiriman barang yang belum sampai ke tempat langganan, sehingga oleh langganan hal tersebut tidak mengakui adanya hutang kepada perusahaan. Dengan adanya surat peryataan piutang kepada langganan maka setiap kesalahan dapat ditelesuri dimana letak kesalahan tersebut, apakah dari pihak langganan atau dari pihak perusahaan.

2. Perusahaan tidak menyelenggarakan daftar umur piutang menurut umurnya, sehingga akan menyulitkan perusahaan. Padahal daftar umur piutang menurut umurnya (aging schedule) merupakan indikasi tidak tertagihnya piutang. Dengan melihat daftar tersebut, perusahaan dapat mengetahui piutang mana yang kemungkinan tidak dapat tertagih, sehingga untuk selanjutnya langganan tersebut sebaiknya tidak diberi kredit lagi.

3. Bagian penjualan seharusnya sebelum mengirim barang kelangganan (menyetujui transaksi penjualan) sebaiknya menghubungi bagian penagihan untuk mendapatkan informasi mengenai kredit langganan yang bersangkutan. Apabila untuk langganan yang mempunyai tunggakan pembayaran diberi kredit, maka kemungkinan menimbulkan piutang tak tertagih, sehingga merugikan perusahaan.

\section{Analisis Sistem Pengendalian Intern Atas Penerimaan Kas}

Kas merupakan perkiraan yang paling likuid dan penting bagi setiap perusahaan selalu membutuhkan kas untuk pembiayaan operasi perusahaan sehari-hari maupun untuk mengadakan investasi baru dalam bentuk aktiva tetap. Kas merupakan perkiraan yang rawan, yang mudah diselewengkan atau, menjadi sasaran kecurangan. Maka dari sudut pengendalian intern atas penerimaan kas memerlukan pengawasan yang paling ketat dan baik. Pengawasan penerimaan kas bertujuan untuk menjamin bahwa semua uang yang diterima telah dicatat dengan segera secara teratur dan catatan penerimaan tersebut menggambarkan secara benar semua uang diterima. Pengendalian intern atas penerimaan kas harus dapat mencegah kemungkinan terjadinya kecurangan atau penyelewengan maka harus dapat segera 
mengungkapkannya. Ketidak cocokan antara jumlah phisik uang kas yang ada dengan catatan saldo kas yang ada dalam pembukuan.

Penerimaan kas dapat berasal dari berbagai sumber seperti dari pelunasan piutang, serta memiliki modal dan lain-lain. Yang akan dibahas disini adalah penerimaan kas yang berasal dari pelunasan piutang :

1. Bagian penagihan menghubungi langganan yang tagihannya telah jatuh tempo melalui telpon.

2. Untuk tagihan yang sudah biasa diambil, bagian tagihan membuat catatan rincian tagihan yang akan dibawa untuk ditagih. Kemudian menyerahkan tanda terima tersebut kepada kolektor yang melakukan penagihan kepada langganan.

3. Uang tunai, cek/bilyet giro yang diterima dari langganan diserahkan kebagian penagihan untuk dicatat pelunasannya pada bukti pelunasan piutang yang bernomor urut tercetak dan dibuat dalam rangkap dua yang didistribusikan sebagai berikut :

Bukti pelunasan piutang lembar 1 : bagian akuntansi

lembar 2 : arsip

4. Uang tunai, cek/giro yang didapat dari hasil penagihan diserahkan kekasir, kemudian kasir mengecak apakah ada giro yang sudah jatuh tempo. Giro yang sudah jatuh tempo keesokkan harinya yang oleh kasir dicatat dulu kedalam buku agenda harian menurut tanggal jatuh tempo.

5. Membuat laporan harian kas/bank atas penerimaan dan penyetoran uang/cek/giro ke bank pada hari itu dan menyerahkannya kebagian akuntansi beserta lampiranlampirannya (bukti setoran yang sudah dicap oleh bank).

6. Bagian akuntnasi mencatat pelunasan piutang ke dalam jurnal dan diposting kebuku besar berdasarkan bukti pelunasan piutang dari bagian penagihan.

7. Setiap akhir bulan dibuat rekonsiliasi bank untuk mencocokan saldo menurut buku bank dengan rekening Koran oleh bagian akuntansi.

Berdasarkan pada prinsip penegndalian intern atas kas/bank yang ada diperusahaan, maka secara umum kondisinya cukup baik. Hal ini telah sesuai dengan prinsip pengendalian intern atas kas yang dikemukan oleh JB Heckert yang dialih bahsakan oleh gunawan hutauruk (2002 : 404), seperti penangan fisik yang harus dipisahkan seluruhnya dari pembukuan, dibuat rekonsiliasi bank setiap akhir bulan untuk mencocokan saldo menurut perusahaan dan saldo bank, semua penerimaan kas harus dicatat sebelum diserahkan pada kasir, namun demikian masih terdapat kelemahan dimana bagian penagihan menghubungi langganan yang tagihannya telah jatuh tempo melalui telpon.

Sedangkan berdasarkan prinsip pengendalian intern menurut JB. Heckert (2002 : 404) mengemukakan bahwa semua penerimaan kas harus dicatat ( dalam hal ini pencatatannya harus berdasarkan pada bukti nyata). Dengan demikian, kondisi tersebut dapat mengakibatkan pihak debitur dapat saja menolak untuk membayar hutangnya dikarenakan tidak ada bukti tertulis yang sah, sehingga penerimaan kas akan ternganggu. Untuk itu sebaiknya penagihan atas debitur harus menggunakan bukti tertulis yang sah, dapat juga setelah melalui telpon dilanjutkan dengan penagihan melalui bukti tertulis yang sah atau datang langsung pada debitur untuk melakukan penagihan, sehingga penerimaan kas perusahaan tidak akan terganggu.

Berdasarkan pada keterangan-keterangan di atas, maka jelas sekali bahwa penyebab meningkatnya piutang tak tertagih (macet), dikarenakan masih lemahnya pengendalian intern perusahan (pengendalian penjualan dan penerimaan kas). 


\section{KESIMPULAN DAN SARAN}

\subsection{Kesimpulan}

1. Adanya perangkapan fungsi penjualan dengan fungsi pemberian kredit. Hal ini dapat menyebabkan kerugian bagi perusahaan, dimana bagian penjualan bekerja kurang efektif sehingga menyebabkan piutang tak tertagih meningkat.

Formulir-formulir yang digunakan CV. Kencana Jaya cukup baik, terlihat pada :

a. Telah digunakannya dokumen atau formulir yang bernomor urut tercetak, sehingga memudahkan pengawasan dan pemakaiannya.

b. Pemakaian dokumen/formulir dipertanggung jawabkan yaitu dengan adanya otorisasi/tanda tangan pada dokumen/formulir yang digunakan.

c. Adanya dokumen/formulir yang dibuat secara rangkap, sehingga dapat mencegah/mengurangi penyelewengan dan kecurangan, serta didistribusi ke bagianbagian yang berkepentingan.

2. Pengendalian intern atas piutang CV. Kencana Jayajuga cukup baik dimana telah terdapat pemisahan fungsi. Namun terdapat beberapa kelemahan pada pengenalian intern atas piutang pada CV. Kencana Jaya sebagai berikut :

a. Perusahaan tidak memuat daftar piutang menurut umurnya. Padahal daftar piutang menurut umurnya dapat memberikan informasi kepada bagian penjualan mengenai tingkat kemampuan langganan dalam pelunasan hutangnya. Sehingga bagian penjualan dapat mempertimbangkan langganan mana yang dapat diberi kredit.

b. Perusahaan tidak mengirim surat pernyataan piutang kepda langganan. Hal ini dapat menimbulkan masalah apabila terdapat perbedaan/kesalahan pencatatan, baik oleh perusahaan maupun oleh langganan.

c. Atas tagihan yang biasa diambil atau tidak biasa diambil dibutuhkan rincian tagihannya.

3. Pengendalian intern atas penerimaan kas cukup baik, dalam hal :

a. Untuk cek/giro yang sudah jatuh tempo dan uang tunai yang diterima sebagai pelunasan piutang oleh kasir disetor ke bank pada hari itu juga atau selambatlambatnya pada awal hari kerja berikutnya.

b. Secara periodic diadakan pencocokan antara tembusan bukti setoran ke bank dengan rekening Koran oleh bagian akuntansi, sehingga apabila terdapat kesalahan dengan mudah dapat diketahui dimana letak kesalahannya.

c. Adanya pemisahaan fungsi, antara fungsi pencatatan dan fungsi penyimpanan; sehingga fisik uang yang ada pada kasir dapat dicocokan dengan jumlah uang menurut catatan akuntansi.

Terdapat beberapa kelemahan, sebagai berikut :

a. Tidak diadakannya pemeriksaan, baik secara periodic maupun secara tiba-tiba terhadap pencocokan jumlah fisik kas yang ada pada kasir dengan jumlah kas menurut catatan yang diselenggarakan oleh kasir.

b. Uang dan cek/giro tidak disimpan di brankas (tempat yang aman)

\subsection{Saran}

Dengan melihat beberapa kelemahan yang terdapat pada system pengendalian intern atas penjualan dan penerimaan kas CV. Kencana Jaya - Bandar Lampung, maka penulis mengemukakan beberapa saran sebagai berikut : 
1. Untuk pemberian kredit diperlukan suatu sektor yang khusus, yaitu sektor yang terpisah dari bagian penjualan. Dengan demikian dapat mencegah adanya piutang yang tidak tertagih.

2. Pesanan dari langganan yang disetujui, harus didasarkan pada order pembelian secara tertulis dari langganan.

3. Perusahaan harus menyelenggarakandaftar piutang menurut umurnya yang dapat dijadikan laporan yang memberikan informasi mengenai kemampuan langganan dalam melunasi hutangnya.

4. Pengiriman surat pernyataan piutang kepada langganan secara periodic sebagai pemberitahuan kepada langganan mengenai hutangnya kepada perusahan. Dan jika terdapat kesalahan, dapat dengan segera diketahui dan diatasi.

\section{DAFTAR PUSTAKA}

Bodnar H. George dan William S. Hopwood. 2002. Sistem Informasi Akuntansi. Jakarta: Salemba Empat.

Harnanto. 2002. Intermediate Accounting. Jogyakarta: BPFE.

Hasibuan, Malayu S.P. 2002. Dasar-dasar Manajemen. Jakarta: Gunung Agung.

Hutauruk, Gunawan. 2002. Prinsip-prinsip akuntansi. Jakarta: Erlangga

Ikatan Akuntan Indonesia. 1995. Standar Akuntansi Keuangan. Jakarta: Salemba Empat.

Kosasih, Ruchyat. 2002. Auditing, Prinsip dan Prosedur. Bandung: Ruchko.

Mulyadi. 2004. Sistem Akuntansi. Jogyakarta: BPFE UGM

Niswonger dan Fess. 2004. Accounting Prinsiples. Jakarta: Aksara Baru.

S. R, Soemarsono. 2002. Pengantar Akuntansi. Jakarta: Salemba Empat.

Theodorus M. Tuanakotta. 2002. Auditing, Petunjuk Pemeriksaan Akuntan Publik. Jakarta: FE UI.

Zaki Baridwan. 2002. Sistem Akuntansi. Jogyakarta: Akademi Akuntansi, YKPN. 
Sengaja Dikosongkan 